\title{
The Western Adriatic shelf clinoform: energy-limited bottomset
}

\author{
Antonio Cattaneo ${ }^{\mathrm{a},{ }^{*}}$, Fabio Trincardi ${ }^{\mathrm{a}}$, Alessandra Asioli ${ }^{\mathrm{b}}$ and Annamaria Correggiari ${ }^{\mathrm{a}}$ \\ a ISMAR (CNR), v. Gobetti 101, 40129 Bologna, Italy \\ b IGG (CNR), c. Garibaldi 37, 35137 Padova, Italy \\ *: Corresponding author : antonio.cattaneo@ifremer.fr
}

\begin{abstract}
:
Clinoforms on modern shelves and slopes, as well as in ancient rock records, are widely recognized as a fundamental building element of continental margin growth. Regardless of their dominant lithology, clinoforms are composed of three geometric elements: topset, foreset and bottomset. Traditionally, much emphasis in the study of clinoforms was put on the geometry of the topset, viewed as the most energetic portion of a clinoform and studied to discern if aggradation was active rather than erosional truncation, and on the foreset, the area with the highest sediment accumulation rates. Here we focus on the factors forcing clinoforms to taper out and on the inferred mechanisms for bottomset creation. We base our analysis on muddy shelf clinoforms, a particular class of clinoforms that is typical of low-gradient settings and is characterized by a substantial component of shoreparallel sediment transport.
\end{abstract}

This paper is based on a large dataset of CHIRP-sonar profiles, bathymetric and isopach maps of the Late Holocene clinoform on the Adriatic shelf, where integrated stratigraphic studies from sediment cores allow a very high (in some cases century-scale) chronological resolution. Knowledge on the dominant oceanographic regime affecting sediment dispersal and, ultimately, clinoform development, has been recently refined during the EuroSTRATAFORM collaboration. Muddy clinoforms are markedly three-dimensional features that cannot be entirely understood solely on two-dimensional shore normal sections. We suggest that this class of clinoform is advection dominated and that an increase in the energy regime at the toe of the foreset may prevent sediment from reaching beyond the transition to the bottomset region.

Keywords: Adriatic; Clinoform; Bottomset; Regime model; Accommodation; Bottom currents 


\section{INTRODUCTION}

The distribution of fine sediment on continental shelves has been the object of detailed studies by physical oceanographers for decades, following the pioneering work by McCave (1972). The location where modern mud preferentially accumulates on the continental shelves depends on several factors, including the amount of suspended particulate matter, the characteristics of sediment sources, and the hydrodynamic energy controlling transport and/or deposition of the suspended fine particles (McCave, 1972). The interaction of these parameters leads to the definition of two distinct sites of mud deposits, which can occur as muddy coastal prisms (shelf clinoforms), nearshore, or mud belts, originally called shelf mud blankets, on the mid- and outer-shelf (McCave, 1972).

Seaward of major deltas, as in the case of the Amazon (Nittrouer et al., 1986), the Yellow River (Alexander et al., 1991), the Fly (Harris et al., 1996) and the Ganges-Brahmaputra (Kuehl et al., 1997), and along the Mediterranean margins (Trincardi et al., 2004a, Cattaneo et al., 2004a), muddy shelf clinoforms develop. Typically, these clinoforms have sediment accumulation rates exceeding $1.5 \mathrm{~cm} \mathrm{yr}^{-1}$ and have been building during the Holocene, after sea level had reached approximately its present position. They extend hundreds of kilometres away from major deltas and exhibit thickness distributions that appear strongly asymmetric with respect to their parent deltas. Both of these characteristics reflect the regional oceanographic processes that redistribute river-borne sediment predominantly along the shelf. In the Mediterranean Sea, late Holocene clinoforms share several additional characteristics having: (1) fine-grained deposits up to $35 \mathrm{~m}$ thick, (2) low-angle foreset dip of 1 degree or less, and (3) bottomset regions characterized by either a sharp termination of seismic reflectors or, more commonly, a low-angle transition to a distal shelf drape. Examples of Mediterranean shelf clinoforms come from the Ebro (Diaz et al., 1990, 1996), the Rhône (Gensous and Tesson, 2003), the Tiber (Bellotti et al., 1994), the Danube (Giosan, 1998), the Thermaikos (Lykousis et al., 2005), and the Adriatic (Cattaneo et al., 2003).

The clinoform is a composite surface, which records the complex interplay between a number of processes such as tidal and wave reworking, diffusion, slope avalanche, and bypass (Nittrouer et al., 1986). Most of the muddy shelf clinoforms with sigmoidal geometry have been documented in high-energy, wave or tide-dominated systems including the Amazon, the Ganges-Brahmaputra, and the Fly (Wright and Coleman, 1973). As a consequence, numerical models explaining the origin of clinoforms are based on gradual variations of the shear stress at the seafloor, induced by waves or bottom currents, as the primary controlling parameter (Pirmez et al., 1998). More recently, other processes, like the formation of fluid muds, have 
been also considered important in the formation of the Amazon clinoform (Cacchione et al., 1995; Kineke and Sternberg, 1995), in the Gulf of Mexico (Bentley et al., 2003), and in the Gulf of Papua, New Guinea (Walsh et al., 2004). Furthermore, in several cases, modern fluvio-deltaic settings build compound systems where progradation takes place in two distinct areas: the coastal plain delta with a subaerial topset, and the subaqueous clinoform, composed of three geometric elements: topset, foreset and bottomset (Nittrouer et al., 1996; Steckler, 1999; Swenson et al., 2005).

In the literature, the topset and foreset regions have received more attention, for example in the definition of the geometric differences between sigmoidal vs. oblique clinoforms (e.g., Mitchum et al., 1977), even if the clinoforms described in early seismic stratigraphic studies were at a much larger scale that those described on modern continental shelves. Traditionally, in the study of muddy shelf clinoforms, the topset region is viewed as the most energetic portion of a clinoform and studied to discern if aggradation is active rather than erosional truncation. In subaqueous deltas (shelf clinoforms) deposited during a relative sea-level stillstand, the main parameter limiting accommodation on the shelf is the intensity of the oceanographic regime and, consequently, the depth of the clinoform rollover point (i.e., the topset-foreset transition) is assumed to reflect the seaward limit beyond which wave-current shear stress, preventing sediment deposition in the topset region, decreases (e.g., DeMaster et al., 1985; Nittrouer et al., 1986; Kuehl et al., 1986; Alexander et al., 1991; Pirmez et al., 1998, Walsh et al., 2004). Topsets experience high near-bed shear stress resulting in dominant sediment bypass (Nittrouer et al., 1996), whereas in the foreset shear stress decreases with increasing water depth and sediment accumulation is at its maximum. In the bottomset, decreasing sediment accumulation is often assumed to simply reflect a decreased sediment flux compared to the more proximal foreset (Pirmez et al., 1998; Driscoll and Karner, 1999).

These simplified explanations may not apply in cases where the whole clinoform accumulates in shallow water depth, as in the case of the Atchafalaya clinoform in the Gulf of Mexico ( $<8$ m water depth; Neill and Allison, 2005). In this shallow clinoform, with limited accommmodation space and relatively low sediment supply, resuspension plays a key role especially on the shallow topset during the passage of cold fronts and occasional cyclonic storms, and provides sediment that is then redistributed further offshore (and alongshore) to the foreset-bottomset region (Neill and Allison, 2005).

Another key element of muddy clinoforms is the presence of a foreset strike which is parallel, over hundreds of kilometers, to the coastline and to the clinoform thickness distribution. This configuration suggests that sediment transport is dominantly sub-parallel to 
the clinform strike (Cattaneo et al., 2003). This observation is consistent with model results showing that the along-strike variability of a clinoform is greater close to a deltaic source, and minimum in distal positions more impacted by along-margin hydrodynamic regimes (Driscoll and Karner, 1999). Bottom currents (whatever their nature, tidal, thermohaline, etc.) may also play a critical role in transporting and trapping sediment on the shelf, as in the case of the East China Sea (Liu et al., in press), even if there are no specific case studies of sediment dynamics and direct oceanographic measurements focussed on bottomset areas.

Here we review the main factors that govern the growth of clinoforms, compare them with our observations on the Adriatic mud clinoform and discuss, in particular, the factors controlling bottomset sediment dynamics. The Po-Adriatic composite shelf clinoform described by Cattaneo et al. (2003), Frignani et al. (2005), Palinkas et al. (2005) and Correggiari et al. (2005a, b) is a particularly interesting example of modern clinoform. The available data allow linking short-term processes and the distribution of energy on the shelf to explain the longer-term growth and the internal geometry of the clinoform. Based on a large dataset of CHIRP sonar profiles, bathymetric maps, seafloor imagery and sediment core data, we propose potential mechanisms to explain the evidence of strike-parallel sediment dispersal in the foreset region and the processes responsible for the formation of bottomsets, including the role of storm wave and shelf currents.

\section{BACKGROUND}

\subsection{Adriatic morphology}

The modern Adriatic Sea is a narrow epicontinental basin (ca. 200 x $800 \mathrm{~km}$ ) with a low axial topographic gradient (ca. $0.02^{\circ}$ ) in the north, and a steeper shelf farther south (Fig. 1). The late Holocene clinoform on the Adriatic shelf reaches up to $35 \mathrm{~m}$ in thickness with a volume of $180 \mathrm{~km}^{3}$ (that correspond to $45010^{9}$ tons of sediment at an average density of $2.5 \mathrm{~g}$ $\mathrm{cm}^{-3}$ ) and rests above a regional downlap surface, the maximum flooding surface (mfs), dated ca. 5.5 cal kyr BP (Asioli, 1996; Correggiari et al., 2001; Cattaneo et al., 2003). On seismic profiles, the Adriatic shelf clinoform is composed of elementary sigmoid units and shows foresets dipping typically $0.5^{\circ}$ to $1.2^{\circ}$ (Figs. 2 and 3). The maximum foreset steepness is consistently observed on sections perpendicular to the coast and reaches the absolute maximum on the E-W stretch North of Gargano Promontory which seems to act as an obstacle for the Western Adriatic Coastal Current (WACC) sediment dispersal system. Highresolution seismic-stratigraphic and tephra correlation indicate that a thin basal unit represents condensed deposition between 5.5 and 3.7 cal. kyr BP over much of the basin (Correggiari et 
al., 2001; Oldfield et al., 2003; Lowe et al., this volume). Above this unit, sediment accumulation rates increased to high values (up to $1.5 \mathrm{~cm} \mathrm{yr}^{-1}$ ) due to the forcing from high frequency climatic or anthropogenic changes (Correggiari et al., 2005a).

\subsection{Supply regime}

Fluvial sediment sources are located almost exclusively along the north and western side of

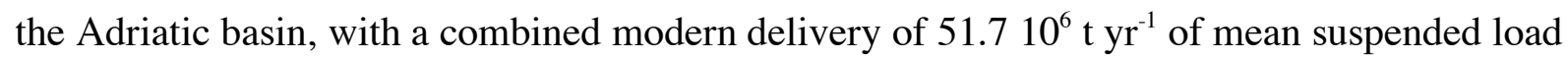
with contributions of $310^{6} \mathrm{t} \mathrm{y}^{-1}$ from eastern Alpine rivers, $1510^{6} \mathrm{t}^{-1}$ from the Po river, 32.2 $10^{6} \mathrm{t}^{-1}$ from the eastern Apennine rivers and $1.510^{6} \mathrm{t} \mathrm{y}^{-1}$ from rivers south of the Gargano promontory (Frignani et al., 1992; Milliman and Syvitski, 1992; Sorgente, 1999; Cattaneo et al., 2003). In spite of a smaller drainage area, the Apennine rivers have a sediment yield double of that of the Po river, mainly in response of the muddy lithologies of their catchment basins. Frignani et al. (2005) calculated the balance between mass accumulation rates

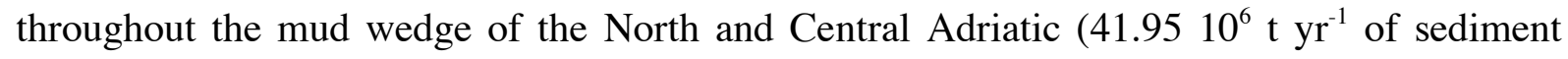
accumulating along the Italian coast) and riverine sediment supply (46.72 $10^{6}{\mathrm{t} \mathrm{yr}^{-1}}^{-1}$ and suggested an annual export of $4.7710^{6} \mathrm{t}$ (6-10\% of the river supply) from the continental shelf to the South Adriatic basin (Fig. 1).

The North Adriatic receives sediment from five main rivers from East to West: the Isonzo, Tagliamento, Livenza, Piave and Adige. The latter is only few km North of the modern Po delta. A typical North Adriatic river is the Tagliamento draining the Southern Alps with a catchment area of $2871 \mathrm{~km}^{2}$. This river is $170 \mathrm{~km}$ long and is characterized by a flashing regime, which results from extremely variable snowmelt and precipitation patterns, with flood events characterised by sharp rising and falling limbs (Gurnell et al., 2001). The 50-year return-period peak discharge is $3500 \mathrm{~m}^{3} \mathrm{~s}^{-1}$ and the 500 years return period exceeds $6000 \mathrm{~m}^{3}$ $\mathrm{s}^{-1}$ (Maione and Machne, 1982). The last major flood event occurred in 1966, when a peak discharge greater than $4000 \mathrm{~m}^{3} \mathrm{~s}^{-1}$ was estimated at Latisana gauging station (Spaliviero, 2003).

\subsection{Energy regime}

The Adriatic basin has a microtidal regime and is dominated by a cyclonic circulation driven by thermohaline currents (Poulain, 2001). The North Adriatic Sea receives the highest river runoff of the entire Mediterranean Sea. The basin is highly sensitive to variations in river runoff and atmospheric conditions because of its shallowness (the Adriatic area North of the Po delta is less than $35 \mathrm{~m}$ deep). River runoff affects the circulation through buoyancy 
input, which is one of the major driving forces of the Western Adriatic Coastal Current (WACC; Orlic et al., 1992), and impacts the entire basin by introducing high loads of sediment and related organic matter, nutrients and pollutants (Miserocchi et al., this volume).

The Po River, with an average annual discharge of $1500 \mathrm{~m}^{3} \mathrm{~s}^{-1}$, accounts for about $50 \%$ of the total northern Adriatic river runoff (Syvitski and Kettner, this volume). A cyclonic circulation gyre is enhanced by the Po River plume and results in trapping fresh waters along the west side of the basin. In this shallow part of the basin, hypoxic events occur, typically, between September and November and reflect: low current velocities at the gyre centre, enhanced water stratification which reduces vertical mixing, and high turbidity which prevents light penetration. Currents are stronger away from the gyre centre, resulting in a prevailing flow to the SE along the Italian coast, a flow that appears consistent with the overall shore-parallel thickness distribution of the late-Holocene clinoform (Cattaneo et al., 2003). Sediment transport is enhanced in the northern Adriatic by the northeasterly Bora wind that enhances waves and currents especially in winter, with an average southward transport along the shelf and little across-shelf transport (Lee et al., 2005).

\section{METHODS}

This work is based on a large dataset of high-resolution CHIRP sonar profiles and sediment cores acquired by ISMAR (CNR) over the last ten years. Seismic-reflection profiles were used both to create a Digital Terrain Model of the wide Adriatic shelf area and to correlate seismic reflectors at the base and within the late Holocene mud wedge. Bathymetric maps (including limited zones with multibeam surveys) and thickness maps are stored in a GIS (ArcGis) to facilitate spatial analyses of regional trends.

In this paper we take advantage of the well-established geologic framework within the Adriatic late Holocene clinoform to present new data on the bottomset area and infer the role of oceanographic energy in clinoform development. The basin-wide correlation of the Adriatic mud clinoform was checked through the analysis of sediment cores that allowed the establishment of a chronology based on several methods, such as foraminifera ecozones, pollen record, magnetic secular variations, tephrochronology, and several tens of AMS ${ }^{14} \mathrm{C}$ dates (Trincardi et al., 1994, 1996; Asioli, 1996; Calanchi et al., 1998; Correggiari et al., 2001; Oldfield et al., 2003; Cattaneo et al., 2003; Asioli and Piva, in press). The work on tephra layers as correlation tools was extended through the search and characterisation of micro tephras (Lowe et al., this volume). Work on short-lived radionuclides has been used to define accumulation rates over the last Century and hints at changes in sediment flux in 
response to short term human impacts (Nittrouer et al., 2004; Frignani et al., 2005; Palinkas and Nittrouer, this volume).

\section{RESULTS}

\subsection{Basin-wide stratigraphic correlation of the late Holocene mud wedge bottomset}

In two dimensions, the Adriatic mud clinoform is a relatively simple feature characterised by a gentle topset, a foreset of variable relief and steepness and a muddy or barren bottomset. The growth of the Adriatic clinoform shows four main characters: 1) the thickness distribution of the mud wedge as a whole is shore-parallel and reflects the dominant oceanographic regime of the basin (Correggiari et al., 2001; Nittrouer et al., 2004); 2) a prominent shore-parallel subaqueous rollover point separates topset and foreset strata in progressively deeper waters from the Po delta (few meters water depth) to the area offshore Gargano (ca. $28 \mathrm{~m}$ water depth); 3) the overall wedge geometry of the central Adriatic clinoform lacks clearly identifiable individual river deltas and prodeltas; 4) the Gargano subaqueous delta, located down-current of the Gargano rocky coast and far from any direct river input, accounts for about $15 \%$ of the total volume of the late-Holocene mud wedge (Cattaneo et al., 2003). All these observations are consistent with the direct observation of the West Adriatic Coastal Current governing sediment dispersal during modern conditions (Poulain, 2001; Nittrouer et al., 2004). Furthermore, the thickness distribution along coastal bulges or buried structural highs is also skewed to the SE with respect to the bulge or bathymetric high as observed around Ancona promontory (Correggiari et al., 2001), Punta Penna (Cattaneo et al., 2003), and Gargano promontory (Ridente and Trincardi, 2002). These evidences suggest an along-strike sediment dispersal feeding the clinoform foresets and demonstrate the importance of currents in redistributing sediment delivered to the basin by the Po and Apennine rivers.

The geometry of the clinoform varies between Ancona and Ortona where a gradual increase in the gradient of the underlying downlap surface, the mfs, occurs (Figs. 1 - 3). Gradient values change from $0.05^{\circ}$ in the North to $0.2^{\circ}$ in the South $\left(\mathrm{KS} 55=0.10^{\circ} ; \mathrm{KS} 12=\right.$ $0.19^{\circ}$; CSS689 $=0.21^{\circ}$, Fig. 2). From North to South the topset becomes steeper and narrower; concurrently, the maximum thickness of the deposit above the mfs increases but becomes more confined landward. It is possible that this change in geometry is associated with a change in the intensity/velocity of shelf currents, also in response to the presence of coastal outbulges. For example, when approaching to the Gargano Promontory, the West Adriatic Coastal Current converges towards the shore pushing the clinoform into a steeper 
and more landward configuration (Fig. 3). This is visible from the bathymetric profiles of the Adriatic clinoform shown in Figure 4 (left) coupled with sediment accumulation values based on ${ }^{210} \mathrm{~Pb}$ activity measurements (modified from Cattaneo et al., 2003). The same technique applied to the Ganges-Brahmaputra subaqueous delta showed a different trend with steepness of the foreset decreasing with distance from the sediment source (Fig. 4, right; modified from Michels et al., 1998).

Figure 5 summarizes stratigraphic information along a sediment-core transect corroborating the correlation of seismic-reflection units with a consistent pattern of ecozones defined by associations of planctonic foraminifera. The core correlation is based on foraminifera counting where the Last Occurrence (LO) of Globorotalia inflata (ca. 5500 cal. yr BP) approximates the basal downlap surface seen on seismic profiles onto which the Adriatic mud clinoform is built. In the Adriatic basin, the LO of G. inflata marks the onset of the modern circulation regime after the attainment of the sea level highstand, when the Adriatic became oligotrophic as it is today (Asioli, 1996). Another significant basin-wide marker in the Adriatic is the LO of Globigerinoides sacculifer (ca. 1200-1300 AD). G. sacculifer is a surface dweller, requiring warm and clear waters, and disappears with an increase in turbidity of the water mass. Therefore the timing of its last occurrence indicates the base of the Little Ice Age (LIA), an interval of substantial increase in sediment accumulation rates in the clinoform (Oldfield et al., 2003; Cattaneo et al., 2003; Correggiari et al., 2005a, b; Lowe et al., this volume; Asioli and Piva, in press).

The transect of Figure 5 also includes cores at the shelf edge and in the Mid Adriatic Deep (MAD) slope basin to document the occurrence of a distal correlative of the shelf clinoform beyond the bottomset. Both in the MAD and in some of the shelf cores, where resolution is higher, the relative abundance of $G$. sacculifer shows significant oscillations that, accompanied by other environmental parameters, reflect supply fluctuations driven by climate and human impact (e.g. sediment core RF93-30, Oldfield et al., 2003). The implication is that the Adriatic mud clinoform does not grow on a steady state basis, but in successive pulses alternated by relatively condensed deposition. This pulsed sedimentation can also bee seen in the bottomset area (e.g. core RF93-30) if analytical resolution is sufficient to detect it.

\subsection{Highly-energetic bottomsets: evidence from seismic stratigraphy and sediment cores}

By analysing the seismic-reflector record of high resolution dataset in the Adriatic clinoform, we can highlight a suite of features in the bottomset that give indirect evidence of sediment dynamics. At distinct locations along the Western Adriaric margin, the bottomset is 
characterised respectively by: 1) a sediment lag where the clinoform advances on a very shallow foundation surface (north Adriatic), or 2) uniform mud deposition in deeper shelf areas except offshore coastal bulges (such as Ancona, Punta Penna, Gargano), or 3) preferential mud deposition on the northwestern side of pre-existing relief, when present (central Adriatic). When all this variability is taken into account, the clinoform appears as a markedly three-dimensional feature that is much more complex than it would appear solely on 2D seismic profiles. In the next section we show examples of the three mentioned cases, where evidence of sediment re-suspension and/or bottom current interaction with seafloor morphology in the bottomset documents the important role of lateral advection.

\subsubsection{Bottomset in shallow water (north Adriatic)}

The Adriatic shelf north of the Po delta is relatively shallow, reaching a maximum depth of $30 \mathrm{~m}$ and having a very subdued gradient (longitudinal gradient of $0.02^{\circ}$ ). Several rivers draining the Southern Alps result in the progradation of deltaic systems that appear progressively less pronounced at the shoreline proceeding East to West (towards the Venice lagoon). These systems tend to build prodelta deposits in water depths that are typically less than $15 \mathrm{~m}$ deep and typically do not extend into water $>20 \mathrm{~m}$. Further offshore, the seafloor is characterised by relict sediment reworked during the last sea level rise and, possibly, afterwards (Correggiari et al., 1996). The Tagliamento prodelta is typical of this setting where progradation likely started a few thousand years ago (Brambati and Venzo, 1967). The maximum thickness of the Tagliamento mud wedge is $8-10 \mathrm{~m}$. The clinoform has a shallow topset connected to the modern shoreface (few meters deep), a shingled internal reflector geometry with a foreset dipping ca. $0.5^{\circ}$, and limited offshore extent (Fig. 6). Although markedly smaller, the mud clinoform of Tagliamento and those of other North Adriatic prodeltas compares and physically correlates to that of the Po and of the Apennine rivers, further south along the western side of the Adriatic (Figs. 1, 2).

Cores recovered through the bottomset of the Tagliamento prodelta allow estimation of the age of the deposits through ${ }^{210} \mathrm{~Pb}$ measurements (Frignani et al., 2005). The ${ }^{210} \mathrm{~Pb}$ activity profile of core GRA87-599 indicates that the entire mud bed above the maximum flooding surface deposited in the last century (Fig. 6). Over the last few millennia, the net deposition in this area was nil due to episodic reworking, while sediment accumulation rate results up to several centimeters per year if calculated over the last century. We consider this evidence as the most striking proof of an actively swept bottomset; in this view, the ${ }^{210} \mathrm{~Pb}$ data indicate that the temporary residence time of sediment in this area can be in the order of at least one 
century (Fig. 6). The evidence of a bottomset episodically swept by currents or waves is consistent with the occurrence of storm waves up to $6 \mathrm{~m}$ (Cavaleri, 2000). Storm wave action accompanied by wind-driven shelf currents may cause the re-suspension of all prodelta sediment. This sediment is likely made available to lateral advection by bottom currents, as indicated by the elongate and shore-parallel thickness distribution of the prodelta deposit in this area. The overall deepening of the clinoform towards the South East suggests that sediment could accumulate down flow in the foreset area of the Western Adriatic clinoform. Furthermore, the evidence of such an energetic bottomset suggests that similar or even more energetic environmental conditions favour re-suspension and erosion of sediment from the foreset and topset regions, as proposed for other shallow water muddy clinoforms (e.g. the Atchafalaya clinoform in the Gulf of Mexico; Neill and Allison, 2005).

\subsubsection{Bottomset influenced by position of coastal outbulges (Ancona, Punta Penna, Gargano)}

A change in coastal orientation may affect along-shore transport and consequently the shape of a clinoform by controlling the depth and distance from shore of the subaqueous rollover point, and the steepness of the foreset (Fig. 3). Changes in coastal configuration, such as the presence of a promontory or coastal bulges, likely induce changes of the direction and velocity of coastal/shelf currents and consequently of shelf erosion/deposition ratio and depth of preferential sediment accumulation. Along the Western Adriatic there are three such examples. First, for about $100 \mathrm{~km}$ south of the Ancona coastal bulge (Fig. 1), the topset of the clinoform broadens and the offlap break slightly diverges from the coastal trend but does not deepen significantly, possibly suggesting decreased energy conditions downcurrent of the coastal constriction to the Western Adriatic Coastal Current (Figs. 2C and 3). Second, an area of enhanced sediment ablation on flat-topped structural highs located in 50-70 m of water depth is particularly evident offshore Punta Penna (Figs. 1 and 3). Third, a similar, but more dramatic, configuration is found around the Gargano Promontory, the most prominent coastal bulge of the entire Adriatic (Figs. 1 and 3).

In particular, offshore Gargano the mud clinoform reaches its maximum thickness and has the steepest foreset along an east-west area elongated for $80 \mathrm{~km}$ parallel to the northern (and up-current) side of the Gargano Promontory and likely reflects flow restriction. Compared to the relatively simple geometry of the Ancona promontory, the Gargano area is complicated by the occurrence of a flat bedrock outcrop in about 50-80 m water depth (Fig. 2F). The rapid cross-shelf transition from a thickness of $30 \mathrm{~m}$ of mud to nil is a good indication of the role played by southward-flowing, bottom-hugging currents that likely prevent deposition in the 
bottomset and cause sediment redistribution along the shelf. Supporting evidence for this topographic effect on the current path and intensity can be found in the gradient seafloor map around the Gargano Promontory, where the foreset is "split" into a shallow-water feature above and a slightly deeper-water component around the submerged structural high (Fig. 3, inset). Also multibeam bathymetry and seafloor backscatter imagery show features with a well developed W-E trend (Fig. 7). For example, Figure 7B shows a grey scale of shadowrelief with superimposed backscatter in color, highlighting elongated areas of high reflectivity (white arrow) that could indicate a change in sediment texture caused by enhanced currents north of the Gargano Promontory.

\subsubsection{Bottomset in areas with topographic irregularities (central Adriatic)}

In the Central Adriatic, the mud clinoform shows small scale irregularities (mud reliefs, few meters high) that can be detected on bathymetric and seismic profiles both in the foreset and in the bottomset (Correggiari et al., 2001; Cattaneo 2004b). Indirect evidence of active bottom currents at the depth of the foreset-bottomset transition comes from the observation of asymmetric sediment accumulation on the flanks of such irregularities (Fig. 8). Preferential mud accumulation occurs systematically updrift of the relief that sticks 3 to $5 \mathrm{~m}$ above the present seafloor (for a discussion on the origin of these reliefs see Trincardi et al., 2000; Correggiari et al., 2001; Trincardi et al., 2004b; Cattaneo et al., 2004b).

In the area offshore Vieste (north of Gargano), similar mud reliefs affect the bottomset of the mud clinoform. In this area, swath bathymetry data indicate that the relief crests are elongated and tend to be oriented sub-parallel to the regional bathymetric contour and the coastline (Fig. 7D). The prevailing orientation of the mud reliefs in the bottomset is also parallel to the strike of the foreset (upslope) where the latter shows the maximum steepness of the entire Adriatic clinoform $\left(>1.2^{\circ}\right.$, Fig. 3). The mud reliefs, whatever their origin is (see discussion in Trincardi et al., 2004), certainly interacted with the bottom current in the area of flow acceleration in front of the Gargano coastal bulge; no direct measurement of this accelerated bottom current is available, but superficial current show clearly this acceleration effect (Poulain, 2001).

\section{DISCUSSION}

\subsection{Mechanisms of muddy clinoform growth}

Progradational clinoforms reflect the interaction of sediment source dynamics, accommodation space fluctuations and sediment dispersal by waves and currents. In general, clinoforms reflect variable proportions of diffusion and lateral advection (Driscoll and 
Karner, 1999). As an end-member of the clinoform family, Gilbert-type deltas, dominated by gravity-driven processes on steeply dipping foresets, are essentially diffusion dominated systems. We regard muddy clinoforms (such as those composing the Adriatic prodelta wedge) as the opposite end-member, dominated by a significant component of advection. Advection becomes the exclusive component of sediment delivery in subaqueous deltas that are nourished by sources located up to hundreds of $\mathrm{km}$ up-current (Cattaneo et al., 2003). Recently Swenson et al. (2005) defined a "phase diagram" for fluviodeltaic clinoforms that is analogous to the ternary diagram that describes subaqueous (fluvial) deltas (Wright and Coleman, 1973). The two end-members represent "terrestrial-dominated" clinoforms (Gilberttype, where diffusion processes dominate) and "basin-dominated" clinoforms like subaqueous deltas. Intermediate conditions generate compound-clinoform geometries (Nittrouer et al., 1996), in which the shoreline rollover separation increases with increasing wave-current driven shallow marine transport processes (Swenson et al., 2005).

Several papers investigated the growth pattern and along-strike variability of the GangesBrahmaputra subaqueous delta (Allison, 1998; Michels et al., 1998). In particular Michels et al. (1998) observed the difference between three bathymetric profiles and coupled them with sediment accumulation rates derived from ${ }^{210} \mathrm{~Pb}$ activity measurements. They pointed out some eastward trends in clinoform growth: a) shallowing of bathymetric profile, b) steepening of the subacqueous delta front, and c) smaller distance between topset and bottomset (Michels et al., 1998; Fig. 4, right). By applying the same technique along strike on the Adriatic mud belt, we observed a different pattern (Fig. 4, left), and formulated the observation in a «process-oriented» perspective, that is in a downcurrent direction (westward in the GangesBrahmaputra, southeastward in the Adriatic). In this sense it is possible to say that a muddy shelf clinoform dominated by lateral advection (Driscoll and Karner, 1999; Cattaneo et al., 2003) tends to show, away from its sediment source: 1) overall deepening of the bathymetric profile; 2) deepening of the rollover point; 3) flattening of the subaqueous delta front; 4) increasing distance between topset and bottomset. This is valid for the Ganges-Brahmaputra subaqueous delta (Figs. 4 right), seems to reflect the shelf dynamics explained by the schemes of McCave (1972; Fig. 9) and is summarized in Figure 10A. In the Adriatic, we noted another superimposed trend, likely due to the presence of coastal outbulges and focusing of shelf currents. In particular, points 1 and 2 above are valid, but there is a steepening of the foreset (in particular around the Gargano promontory) likely due to the increased slope of the foundation surface (as suggested by Pirmez et al., 1998) and to the confining effect of enhanced shelf current (see the proposed scheme of Figure 10B). Both at the latitude of 
Ancona and Gargano there are current gyres depending from the shape of the basin (Poulain, 2001) that could enhance this effect of mud confinement.

Possible mechanisms of clinoform growth on the Adriatic shelf include: 1) bottom Ekman transport (Cattaneo et al., 2004a; Puig et al., this volume), 2) down-welling and seaward bottom flows, observed when winds pile water against the coast (Nittrouer et al., 2004), or 3) gravity flows triggered from river floods that are not observed today, but appear possible before dam construction in the Apennine Rivers (Syvitski and Kettner, this volume). The morphology and thickness distribution of the Adriatic shelf clinoform reflects sediment transport by the WACC parallel to the clinoform strike (Cattaneo et al., 2004a). The dominance of this kind of mechanism is evident when the resulting sediment thickness distribution is time-averaged over complementary intervals (the last century, the last 500 years and the last ca. 5000 years) all characterised by depocentres that are elongated parallel to the coast (Cattaneo et al. 2004a).

While most models assume that clinoforms grow essentially as supply-limited systems (i.e., they build in equilibrium with sediment supply), the Adriatic example shows that the growth of a clinoform can be energy-confined as it reflects the impact of shore-parallel currents. In the Adriatic, the WACC, which increases energy in the bottomset, prevents sediment from escaping the foreset region and transfers the sediment all the way to the area off the Gargano promontory (Cattaneo et al., 2003). Where advection dominates, like in the case of the Adriatic muddy clinoform, the seaward extent of the foreset appears limited by increasing energy at the seafloor rather than by a relatively simple decrease in sediment flux from proximal to distal locations along a shore-normal transect. Evidence for this are particularly convincing in areas where a complex sea floor morphology develops in response to soft sediment deformation (Cattaneo et al., 2004b; Trincardi et al., 2004b) or in areas where tectonic deformation during the Quaternary defines bathymetric highs with locally steeper flanks against which shore-parallel currents accelerate.

\subsection{Implications for clinoform modeling}

\subsubsection{Depth and morphology of the fundation surface}

The deposition of fine sediment particles is principally dependent on hydrodynamic, which has to be low to allow settling. However, the morphological environment may also influence sediment deposition and the concept of foundation surface was introduced in sequence stratigraphy to define the importance of the surface morphology onto which a clinoform is emplaced (Helland-Hansen, 1994 and 1996). This factor is relevant in at least one of three 
ways: 1) the depth of the surface onto which a progradational wedge advances controls the preservation potential of the deposit; on the shallow North Adriatic shelf, rivers build shingled units that are thinner and undergo more dramatic resuspension than their Apennine counterparts (all prograding in water depths that are at least twice as deep); 2) on local scale, the occurrence of pre-existing depressions may be preferentially filled compared to other adjacent zones; and/or 3) the presence of rock outcrops, that may be swept preferentially by currents, can also create hydrodynamic protection (defining local lower energy areas), functioning as a barrier for the sediments transported by the bottom nepheloid layer, which is intensified during storms (Drago et al., 1999; Puig et al., this volume).

\subsubsection{Clinoforms in $3 D$}

In the Adriatic clinoform, the most relevant character is that the strike of the foreset is everywhere consistently sub-parallel to the coast and to the sediment-laden WACC coastal current. A numerical model based on time-averages marine sediment dynamics supports an important role of shelf current advection in the generation of the Adriatic shelf clinoform (Niedoroda et al., 2005). The significant advection to the SE, however, does not generate a clinoform that progrades in the same direction of the current, but at some $90^{\circ}$ towards the basin. Furthermore, along the clinoform strike, we observe a basin-scale deepening of both the rollover point and the bottomset that reflect a concurrent deepening of the foundation surface. These changes reflect a lateral change in the balance between supply and effective accommodation, i.e. the space that can effectively be exploited by accumulation and is limited by the oceanographic energy term (Thorne and Swift, 1991). The definition of accommodation in terms of "regime" is at the base of the regime model of Thorne and Swift (1991). Lateral advection of shelf clinoforms implies a highly energetic environment as a limiting factor for sediment accumulation in the bottomset and as a major factor conducive to downcurrent elongation of shelf clinoform.

Simplified geological models explain the growth of clinoforms as two-dimensional features where sediment is transported exclusively across a continental margin. Instead, clinoforms, like all strata packages, are three-dimensional objects and reflect the interplay between water depth, sediment supply, and hydrodynamics (Driscoll and Karner, 1999). The three-dimensional view of clinoform and the adequate consideration of the energetic regime at the seafloor could also help understand the shape and location of sediment bodies on the shelf. In the case of late Holocene muddy shelf clinoforms off the major Mediterranean rivers, this combination of factors could account for a major component of sediment advection along 
the margin. It is not paradoxical to suppose that sediment accumulating on the foreset is coming from a lateral source rather than from a direction perpendicular to the shoreline, as frequently assumed by oversimplified sedimentation models. Additionally, part of the sediment could even derive from the bottomset area updrift of the foreset accumulation zone, if we have to consider the bottom Ekman effect of a strong bottom current flowing roughly parallel to a margin. Studying clinoforms in 3D is interesting to evaluate the spatial variations of sediment accumulation within the clinoform sub-elements (in particular the downcurrent variations for advection dominated muddy shelf clinoforms). This observation could lead to more realistic simulations of sediment dynamics in stratigraphic modeling.

In the shallow northern Adriatic the bottomset is directly impacted by the action of storm waves resulting in punctuated events of sediment erosion and removal, while in the central Adriatic an important limiting factor in bottomset sedimentation could be represented by bottom currents. At any site, on the Adriatic shelf, the component of clinoform growth in a basinward direction seems to be dominated at present by bottom Ekman transport, although transport by gravity flows could have been important when Apennine Rivers were not dammed (until about 50 years ago). The physical processes that govern the clinoform growth today were likely at work over the last few thousand of years even though sediment supply was not steady and extensive river damming since the 1950s induced further limitations. Secular- to decadal-scale supply fluctuations can be precisely defined based on integrated stratigraphic techniques.

We presented indirect evidence for this increased energy level in both cases. An enhanced integration of physical oceanography observations and stratigraphic studies could test these hypotheses and bridge the gap between process studies and stratigraphic reconstructions. This evidence remains in part indirect, especially in the bottomset area, and would need further experimental work in terms of "stratigraphically-driven" current measurements (Ogston et al., in press). This will also provide new tools to stratigraphic modelling to predict more effectively sediment depositional patterns on continental shelves, to the benefit of a vast community of shelf management authorities.

\section{CONCLUSION}

The Adriatic shelf clinoform originated after the attainment of the present sea level high stand through a mechanism of prevailing coast-parallel sediment transport from the main sediment entry point in the North (the Po delta) to its farthest reach, several hundreds of kilometres down-flow and the sequestering of sediment delivered by a multitude of Apennine 
rivers along the Italian coast. This muddy clinoform records substantial changes of energy patterns both spatially (from the shallow North Adriatic to the South), and in time, with variable growth pace through decades to millennia. From North to South, the laterally extensive Adriatic clinoform displays an overall increase of: 1) the depth of the rollover point (less than $8 \mathrm{~m}$ in the North and about $30 \mathrm{~m}$ in the South); 2) the extent of the topset region down-flow of capes and promontories, possibly indicating spreading of bottom currents; 3 ) the steepness of the foreset in areas typically up current of capes, promontories or basement shoals, suggesting the impact of flow confinement and acceleration; 4) the sediment accumulation rates in the foreset. These characters are consistent with the clinoform being nourished from a significant component of lateral advection of fine sediment in a direction sub-parallel to the foreset strike.

Based on the Adriatic dataset, we propose that the thinning of strata in a clinoform bottomset may reflect increased environmental energy rather than just a passive decrease in sediment supply. The energy factor that limit dynamically the accommodation is represented by storm waves in the shallow North Adriatic, by strong shelf currents in the Central and South Adriatic. These processes result in decreased sediment accumulation or sediment resuspension in the bottomset, limiting the basinward growth of the clinoform. Furthermore, the Western Adriatic Coastal Current, driven by the formation of cold dense waters in the North, flows parallel to the clinoform strike and induce a lateral translation of sediment, with the formation of an elongated shore-parallel clinoform body that is advection-dominated. The Western Adriatic Coastal Current is particularly energetic in the foreset-bottomset transition in the Central Adriatic, where the clinoform foreset is steeper, the foundation surface and the rollover point deeper and the overall progradational wedge thicker. These observations are consistent with limited direct current measurements at the base of the foreset (e.g., Puig et al., this volume) and with numerical modeling run on the Adriatic clinoform formation (Niedoroda et al., 2005).

It is commonly implied that decreased sediment accumulation rates in the bottomset reflect a decrease in sediment flux beyond the foreset. In this view, the bottomset would passively reflect the trapping of sediment in the foreset. Based on the Adriatic example, we suggest that muddy clinoforms, where advection is dominant and sub-parallel to the clinoform strike, are confined to their position through a substantial increase of environmental energy in the bottomset region. In this view, sediment is trapped landward of the bottomset and is forced to move along strike in the foreset region rather than offshore across the bottomset. These conclusions reinforce the view of clinoforms as reflecting a dynamic balance between energy 
and sediment accumulation and could be extended to other muddy clinoforms on the Mediterranean shelf and elsewhere.

\section{ACKNOWLEDGEMENTS}

Financial support was provided from projects EURODELTA (European Co-ordination on Mediterranean and Black Sea Prodeltas; EC contract n. EVK3-CT-2001-20001) and EUROSTRATAFORM (EC contract n. EVK3-CT-2002-00079). We thank captain and crew of N/O Urania (CNR) for chirp sonar profiles and sediment cores, and of N/O Odin Finder for multibeam bathymetry and seafloor imagery (GNDT project Rischi Sottomarini). We thank Galderic Lastras for the treatment of multibeam bathymetry and backscatter data off Gargano, and Federica Foglini for helping with the GIS of Adriatic data. Reviewers S. Berné and S. Milli enhanced the manuscript with their comments. Much of the results represent an offspring of fruitful discussions with numerous participants to the COMDELTA meeting, Aix-en Provence, October 2003. This is ISMAR-Bologna (CNR) contribution n. XXXX. 


\section{REFERENCES}

Alexander, C.R., DeMaster, D.J., Nittrouer, C.A., 1991. Sediment accumulation in a modern epicontinental-shelf setting: The Yellow Sea. Marine Geology 98, 51-72.

Allison, M.A., 1998. Historical changes in the Ganges-Brahmaputra delta front. Journal of Coastal Research 14, 1269-1275.

Asioli, A., 1996. High resolution foraminifera biostratigraphy in the central Adriatic basin during the last deglaciation: A contribution to the PALICLAS project. Memorie Istituto Italiano Idrobiologia 55, 197-217.

Asioli, A., Piva, A. Il ruolo dei foraminiferi nelle ricostruzioni paleoceanografiche e paleoclimatiche: esempi dal Mediterraneo Centrale (Adriatico) per il tardo Olocene attraverso un approccio multidisciplinare. Atti del Convegno Interdisciplinare La ricerca paleobotanica/paleopalinologica in Italia: stato dell'arte e spunti di interesse (Modena, 2021 novembre 2003). Informatore Botanico Italiano, in press.

Asioli, A., Trincardi, F., Lowe, J.J., Ariztegui, D., Langone, L., Oldfield, F., 2001. Submillennial climatic oscillations in the Central Adriatic during the last deglaciation: paleoceanographic implications. Quaternary Science Reviews 20, 33-53.

Bellotti, P., Chiocci, F.L., Milli, S., Tortora, P., Valeri, P., 1994. Sequence stratigraphy and depositional setting of the Tiber Delta; integration of high-resolution seismics, well logs, and archeological data. Journal of Sedimentary Research 64, 416-432.

Bentley, S.J., Roberts, H.H., Rotondo, K., 2003. The sedimentology of muddy coastal systems: The research legacy and new perspectives from the Coastal Studies Institute. GCAGS/GCSSEPM Transactions 53, 52-63.

Brambati, A., Venzo G.A., 1967. Recent sedimentation in the Northern Adriatic Sea between Venice and Trieste. Studi Trentini di Scienze Naturali v. XLIV/2, 2002-274.

Cacchione, D.A., Drake, D.E., Kayen, R.W., Sternberg, R.W., Kineke, G.C., Tate, G.B., 1995. Measurements in the bottom boundary layer on the Amazon subaqueous delta. Marine Geology 125, 235-257.

Calanchi, N., Cattaneo, A., Dinelli, E., Gasparotto, G., Lucchini F., 1998. Tephra layers in the late-Quaternary sediments of the central Adriatic sea. Marine Geology 149, 181-199.

Cattaneo, A., Correggiari, A., Langone, L., Trincardi, F., 2003. The late-Holocene Gargano subaqueous delta, Adriatic shelf: Sediment pathways and supply fluctuations. Marine Geology 193, 61-91.

Cattaneo, A., Trincardi, F., Langone, L., Asioli, A., Puig, P., 2004a. Clinoformation Generation on Mediterranean Margins. Oceanography 17, 104-117.

Cattaneo, A., Correggiari, A., Marsset, T., Thomas, Y., Marsset, B., Trincardi, F., 2004b. Seafloor undulation patterns on the Adriatic shelf and comparison to deep-water sediment waves. Marine Geology 213, 121-148.

Cavaleri, L., 2000, The oceanographic tower Acqua Alta - activity and prediction of sea states at Venice: Coastal Engeneering 39, 29-70.

Correggiari, A., Field, M., Trincardi, F., 1996. Late Quaternary large dunes on the sedimentstarved Adriatic shelf. In: De Batist, M., Jacob, P. (Eds.), Geology of Siliciclastic Shelf Seas. Geological Society Special Publication 117, 155-169.

Correggiari, A., Trincardi, F., Langone, L., Roveri, M., 2001. Styles of failure in late Holocene highstand prodelta wedges on the Adriatic shelf. Journal of Sedimentary. Research 71, 218-236.

Correggiari, A., Cattaneo, A., Trincardi, F., 2005a. Depositional patterns in the LateHolocene Po delta system. In Bhattacharya, J.P., Giosan, L. (Eds.), River Deltas: Concepts, Models and Examples. SEPM Special Publication 83, 365-392. 
Correggiari, A., Cattaneo, A., Trincardi, F., 2005b. The modern Po Delta system: lobe switching and asymmetric prodelta growth. Marine Geology 222-223, 49-74.

DeMaster, D.J., McKee, B.A., Nittrouer, C.A., Jiangchu, Q., Guodong, C., 1985. Rates of sediment accumulation and particle reworking based on radiochemical measurements from continental shelf deposits in the East China Sea. Continental Shelf Research 4, 143-158.

Diaz, J.I., Nelson, C.H., Barber, J.H., Jr., Giró, S. 1990. Late Pleistocene and Holocene sedimentary facies on the Ebro continental shelf. Marine Geology 95, 333-352.

Diaz, J.I., Palanques, A., Nelson, C.H., Guillen, J., 1996. Morphostructure and sedimentary of the Holocene Ebro prodelta mud belt (northwestern Mediterranean Sea). Continental Shelf Research 16, 435- 456.

Drago, T., Araújo, F., Valério, P., Weber, O., Jouanneau, J.M., 1999. Geomorphological control of fine sedimentation on the northern Portuguese shelf. Bol. Inst. Esp. Oceanogr. $15,111-122$.

Driscoll, N.W., Karner, G.D., 1999. Three-dimensional quantitative modeling of clinoform development. Marine Geology 154, 383-398.

Frignani, M., Langone, L., Pacelli, M., Ravaioli, M., 1992. Input, distribution and accumulation of dolomite in sediments of the Middle Adriatic Sea. Rapp. Comm. int. Mer Medit. 33, p. 324.

Frignani, M., Langone, L., Ravaioli, M., Sorgente, D., Alvisi, F., Albertazzi, S., 2005. Fine sediment mass balance in the western Adriatic continental shelf over a century time scale. Marine Geology 222-223, 113-133.

Gensous, B., Tesson, M., 2003. L'analyse des depôts postglaciaires et son application à l'étude des séquences de depôts du Quaternaire terminal sur la plate-forme au large du Rhône (golfe du Lion). Bulletin de la Société Géologique de France 174, 401-419.

Giosan, L., 1998. Long term sediment dynamics on Danube delta coast. In: Dronkers, J., Scheffers, M. (Eds.), Physics of estuaries and coastal seas. Balkema, Rotterdam, Netherlands, 365-376.

Gurnell, A.M., Petts, G.E., Hannah, D.M., Smith, B.P.G., Edwards, P.J., Kollmann, J., Ward, J.V., Tockner, K., 2001. Riparian vegetation and island formation along the gravel-bed Fiume Tagliamento, Italy. Earth Surface Processes and Landforms 26, 31-62.

Harris, P.T., Pattiaratchi, C.B., Keene, J.B., Dalrymple, R.W., Gardner, J.V., Baker, E.K., Cole, A.R., Mitchell, D., Gibbs, P., Schroeder, W.W., 1996. Late Quaternary deltaic and carbonate sedimentation in the Gulf of Papua foreland basin: response to sea-level change. Journal of Sedimentary Research 66, 801-819.

Helland-Hansen, W., Gjelberg, J.G., 1994. Conceptual basis and variability in sequence stratigraphy: a different perspective. Sedimentary Geology 92, 31-52.

Helland-Hansen, W., Martinsen, O.J., 1996. Shoreline trajectories and sequences: description of variable depositional-dip scenarios. Journal of Sedimentary Research 66, 670-688.

Kineke, G.C., Sternberg, R.W., 1995. Distribution of fluid muds on the Amazon continental shelf. Marine Geology 125, 193-233.

Kuehl, S.A., DeMaster, D.J., Nittrouer, C.A., 1986. Nature of sediment accumulation on the Amazon continental shelf. Continental Shelf Research 6, 209-225.

Kuehl, S.A., Levy, B.M., Moore, W.S., Allison, M.A., 1997. Subaqueous delta of the GangesBrahmaputra river system. Marine Geology 144, 81-96.

Lee, C.M., Askari, F., Book, J., Carniel, S., Cushman-Roisin, B., Dorman, C., Doyle, J., Flament, P., Harris, C.K., Jones, B.H., Kuzmic, M., Martin, P., Ogston, A.S., Orlic, M., Perkins, H., Poulain, P.-M., Pullen, J., Russo, A., Sherwood, C., Signell, R.P., Thaler Detweiler, D., 2005. Northern Adriatic Response to a Wintertime Bora Wind Event. Eos Transactions 86/16, 157-168. 
Liu, J.P., Xu, K.H., Li, A.C., Milliman, J.D., Velozzi, D.M., Xiao, S.B., Yang, Z.S. Flux and Fate of Yangtze River Sediment Delivered to the East China Sea. Geomorphology, in press.

Lowe, J.J., Blockley, S.,Trincardi, F., Asioli, A., Cattaneo, A., Matthews, I.P., Pollard, A.M., Wulf, S. Age modelling of late Quaternary marine sequences in the Adriatic: towards improved precision and accuracy using volcanic event stratigraphy. Continental Shelf Research, this volume.

Lykousis, V., Karageorgis, A.P., Chronis, G.Th., 2005. Delta progradation and sediment fluxes since the last glacial in the Thermaikos Gulf and the Sporades Basin, NW Aegean Sea, Greece. Marine Geology 222-223, 381-397.

Maione, U., Machne, G., 1982. Studio sulla formazione e sulla propagazione delle piene del fiume Tagliamento-Relazione tecnica. Regione Friuli-Venetia Giulia, Udine.

McCave, I.N., 1972. Transport and escape of fine-grained sediment from shelf areas. In: Swift, D.J.P., Duane, D.B., Pilkey, O.H. (Eds.), Shelf Sediment Transport: Process and Pattern, Van Nostrand Reinhold, New York, 225-248.

Michels, K.H., Kudrass, H.R., Hübscher, C., Suckow, A., Wiedicke, M., 1998. The submarine delta of the Ganges-Brahmaputra: cyclone-dominated sedimentation patterns. Marine Geology 149, 133-154.

Milliman, J.D., Syvitski, J.P.M., 1992. Geomorphic/tectonic control of sediment discharge to the ocean: the importance of small mountainous rivers. Journal of Geology 100, 525-544.

Miserocchi, S., Langone, L., Tesi, T. Concentration and isotopic composition of organic carbon within a flood layer in the Po River prodelta (Adriatic Sea). Continental Shelf Research, this volume.

Mitchum, R.M., Jr., Vail, P.R., Sangree, J.B., 1977. Seismic stratigraphy and global changes of sea level, part 6: Stratigraphic interpretation of seismic reflection patterns in depositional sequences. In: Payton, C.E. (Ed.). Seismic Stratigraphy-Applications to Hydrocarbon Exploration. AAPG Memoir 26, 117-133.

Neill, C.F., Allison, M.A., 2005. Subaqueous deltaic formation on the Atchafalaya Shelf, Louisiana. Marine Geology 214, 411-430.

Niedoroda, A.W., Reed, C.W., Das, H., Fagherazzi, S., Donoghue, J.F., Cattaneo, A., 2005. Analyses of a large-scale depositional clinoformal wedge along the Italian Adriatic coast. Marine Geology 222-223, 179-192.

Nittrouer, C.A., Kuehl, S.A., DeMaster, D.J., Kowsmann, R.O., 1986. The deltaic nature of Amazon shelf sedimentation. Geological Society of America Bulletin 97, 444-458.

Nittrouer, C.A., Kuehl, S.A., Figueiredo, A.G., Allison, M.A., Sommerfield, C.K., Rine, J.M., Faria, E.C., Silveira, O.M., 1996. The geological record preserved by Amazon shelf sedimentation, Continental Shelf Research 16, 817-841.

Nittrouer, C.A., Miserocchi, S., Trincardi, F., 2004. The PASTA Project: Investigation of Po and Apennine Sediment Transport and Accumulation. Oceanography 17, 46-57.

Ogston, A.S., Sternberg, R.W., Nittrouer, C.A. New advances in fine-grained sediment transport. In: Brink, K., Robinson, A. (Eds.), The Sea. Volume 13, Chapter 4, in press.

Oldfield, F., Asioli, A., Accorsi, C.A., Mercuri, A.M., Juggins, S., Langone, L., Rolph, T., Trincardi, F., Wolff, G., Gibbs, Z., Vigliotti, L., Frignani M., Van der post, K., Branch, N., 2003. A high resolution late-Holocene palaeo environmental record from the central Adriatic Sea. Quaternary Science Reviews 22, 319-342.

Orlic, M., Gacic, M., La Violette, P.E., 1992. The currents and circulation of the Adriatic Sea. Oceanologica Acta 15, 109-124.

Palinkas, C.M., Nittrouer, C.A. Modern sediment accumulation on the Po shelf, Adriatic Sea. Continental Shelf Research, this volume. 
Palinkas, C.M., Nittrouer, C.A., Wheatcroft, R.A., Langone, L., 2005. The use of ${ }^{7}$ Be to identify event and seasonal sedimentation near the Po River delta, Adriatic Sea. Marine Geology 222-223, 95-112.

Pirmez, C., Pratson, L.F., Steckler, M.S., 1998. Clinoform development by advectiondiffusion of suspended sediment: Modeling and comparison to natural systems. Journal of Geophysical Research 103(B10), 24,141-2,4157.

Poulain, P.-M., 2001. Adriatic Sea surface circulation as derived from drifter data between 1990 and 1999. Journal of Marine Systems 29, 3-32.

Puig, P., Ogston, A.S., Guillén, J., Fain, A.M.V., Palanques, A. Sediment transport processes from the topset to the foreset of a crenulated clinoform (Adriatic Sea). Continental Shelf Research, this volume.

Ridente, D., Trincardi, F., 2002. Eustatic and tectonic control on deposition and lateral variability of Quaternary regressive sequences in the Adriatic basin. Marine Geology 184, 273-293.

Sigl, W., 1973. Der Golf von Manfredonia (Südliche Adria). I. Die fazielle Differenzierung der Sedimente. Senckenbergiana Marit. 5, 3-49.

Sorgente, D., 1999. Studio della sedimentazione attuale e recente nel medio Adriatico attraverso l'uso di traccianti radioattivi. PhD Thesis, University of Bologna, $178 \mathrm{pp}$.

Spaliviero, M., 2003. Historic fluvial development of the Alpine-foreland Tagliamento River, Italy, and consequences for floodplain management. Geomorphology 52, 317-333.

Steckler, M.S., 1999. High-resolution sequence stratigraphic modeling 1: the interplay of sedimentation, erosion, and subsidence. In: Harbaugh, J.W., Watney, W.L., Rankey, E.C., Slingerland, R., Goldstein, R.H., Franseen, E.K. (Eds.), Numerical experiments in stratigraphic and sedimentologic computer simulations. SEPM special publication 62, 139149.

Stuiver, M., Reimer, P.J., Bard, E., Beck, J.W., Burr, G.S., Hughen, K.A., Kromer, B., McCormac, F.G., v.d. Plicht, J., Spurk, M., 1998. INTCAL98 Radiocarbon age calibration 24,000-0 cal BP. Radiocarbon 40, 1041-1083.

Swenson, J.B., Paola, C., Pratson, L.F., Voller, V.R., Murray, A.B., 2005. Fluvial and marine controls on combined subaerial and subaqueous delta progradation: Morphodynamic modeling of compound-clinoform development, Journal of Geophysical Research, 110, F02013, doi:10.1029/2004JF000265.

Syvitski, J.P.M., Kettner, A.J. On the Flux of Water and Sediment into the Northern Adriatic. Continental Shelf Research, this volume.

Thorne, J.A., Swift, D.J.P., 1991. Sedimentation on continental margins: VI. A regime model for depositional sequences, their component systems tracts, and bounding surfaces. In: Swift, D.J.P., Oertel, G.F., Tillman, R.W., Thorne, J.A. (Eds.), Shelf Sand and Sandstone Bodies - Geometry, Facies and Sequence Stratigraphy. International Association of Sedimentologists Special Publication 14, 189-255.

Trincardi, F., Correggiari, A., Roveri, M., 1994. Late Quaternary transgressive erosion and deposition in a modern epicontinental shelf: The Adriatic Semienclosed Basin. GeoMarine Letters 14, 41-51.

Trincardi, F., Asioli, A., Cattaneo, A., Correggiari, A., Langone, L., 1996. Stratigraphy of the late-Quaternary deposits in the Central Adriatic basin and the record of short-term climatic events. In: Guilizzoni, P., Oldfield, F. (Eds.), Palaeoenvironmental Analysis of Italian Crater Lake and Adriatic Sediments. Memorie Istituto Italiano di Idrobiologia 55, 39-70.

Trincardi, F., Cattaneo, A., Correggiari, A., Masson, D.G., Hühnerbach, V., Jacobs, C., Carrà, D., Magagnoli, A., Penitenti, D., Ridente, D., Roveri, M. 2000. Evidence of giant fluidescape features in late-Holocene deposits on the Adriatic shelf. Giornale di Geologia 62, 528. 
Trincardi, F., Cattaneo, A., Correggiari A., 2004a. Mediterranean prodelta systems: natural evolution and human impact investigated by EURODELTA. Oceanography 17, 34-45.

Trincardi, F., Cattaneo, A., Correggiari, A., Ridente, D., 2004b. Evidence of soft-sediment deformation, fluid escape, sediment failure and regional weak layers within the lateQuaternary mud deposits of the Adriatic Sea. Marine Geology 213, 91-119.

Walsh, J.P., Nittrouer, C.A., Palinkas, C.M., Ogston, A.S., Sternberg, R.W., Brunskill, G.J., 2004. Clinoform mechanics in the Gulf of Papua, New Guinea. Continental Shelf Research 24, 2487-2510.

Wright, L. D., Coleman, J.M., 1973. Variations in morphology of major river deltas as a function of ocean wave and river discharge regimes, AAPG Bulletin 57, 177-205. 


\section{FIGURE CAPTIONS}

Figure 1. Bathymetric map of the Adriatic Sea (gray lines) with superimposed (black lines) thickness map of the late Holocene deposits (from Correggiari et al., 2001; Cattaneo et al., 2003). Note the position of the late Holocene mud wedge depocenters off the Po delta, south of Ancona along the southwestern side of the basin and southeast of the Gargano promontory. All the seismic profiles and sediment cores showed in this paper are located here. The limits between North, Central and South Adriatic are considered roughly $44^{\circ}$ and $42^{\circ}$ lat $\mathrm{N}$, respectively.

Figure 2. Seismic-reflection profiles (CHIRP sonar) across the Adriatic shelf show distinct clinoform geometries at the same vertical and horizontal scales: A) Profile VE14, in the northern Adriatic, shows a very shallow clinoform at the mouth of the Tagliamento River with the bottomset in ca. $15 \mathrm{~m}$ w.d. B) A similar situation characterises the northern (and steeper) slope of the Po prodelta, advancing in $30 \mathrm{~m}$ water depth (profile POP6). C-D) South of Ancona, profiles KS55 and KS12 show that the clinoform advances in deeper waters and has a markedly sigmoidal geometry. E) Profile CSS689 offshore Pescara, further South, shows that the clinoform advances in deeper waters, the foreset is steeper and characterised by complex undulations in the foreset and bottomset (Correggiari et al., 2001; Cattaneo et al., 2004b). F) Northeast of the Gargano promontory (profile AMC167) the clinoform shows abrupt seismic-reflector terminations on a flat bedrock outcrop in $50 \mathrm{~m}$ w.d., suggesting the effect of focusing of bottom currents.

Figure 3. Slope angle map of the Adriatic shelf shallower than $120 \mathrm{~m}$. Note the gradient increase in the foreset region of the clinoform and the progressive increase of foreset dip in the area north of the Gargano Promontory, upflow with respect to the SW-ward flowing WACC (West Adriatic Coastal Current). In the blow up around the Gargano Promontory note that the foreset of the mud clinoform "bifurcates" around the structural high of the relief.

Figure 4. Bathymetric profiles (above) and sedimentation rates (based on ${ }^{210} \mathrm{~Pb}$ activity) on the same profiles (below) for the Adriatic shelf clinoform (left, modified from Cattaneo et al., 2003), and for the Ganges-Brahmaputra subaqueous delta (right, modified from Michels et al., 1998). In both cases the foreset shows the maximum sediment accumulation rate. Note that in the Ganges-Brahmaputra there is a down current (from profile P3 to P1) deepening of 
the bathymetric profile and rollover point, an increase in the topset-bottomset distance and a flattening of the foreset. In the Adriatic, instead, the foreset is steeper in the down current direction (from Po to East Gargano), as a possible result of bottom current forcing sediment against the basement high and coastal outbulge of the Gargano promontory.

Fig. 5. Basin-wide stratigraphic correlation of sediment cores (located in Fig. 1) from the Adriatic shelf clinoform. Core RF93-30 was taken from the central Adriatic clinoform, where the bottomset deposit provides a continuous record of sedimentation during the late Holocene (Oldfield et al., 2003). Core AMC99-01 is a reference stratigraphic core in the center of the basin. The scheme is based on seismic correlation of the cored stratigraphic units (Trincardi et al., 1996, Correggiari et al., 2001, Cattaneo et al., 2003), magnetic susceptibility log matching, ${ }^{14} \mathrm{C}$ AMS datings, foraminifera ecozones, and tephrochronology (Asioli, 1996; Asioli et al., 2001; Oldfield et al. 2003; Asioli and Piva, in press). The maximum flooding surface at the base of the late Holocene clinoform (mfs, thick black line) corresponds to the last occurrence of $G$. inflata and an interval of low magnetic susceptibility values. A thick dashed line corresponds to the last occurrence of $G$. sacculifer. Radiocarbon dates are reported from papers mentioned in Table 1, and represent for cores AN97-2, AN97-15 and RF93-30 "calibrated age range" (yr BP; calibration with Calib 4.3), for cores PAL94-8 and PAL94-9 “calibrated age (yr BP) \pm 1 sigma error (yr)” (Stuiver et al., 1998).

Figure 6. Seismic profile VE14 (same as on Fig. 2A, enlarged) with sediment cores obtained in progressively deeper waters. The lithologic logs and magnetic susceptibility curves of cores VE04-19 and VE04-21 show alternating silty clay with discrete silt and very fine sand layers above a condensed surface representing the maximum flooding surface coinciding with the transgressive ravinement surface. Core GRA87-599 was taken in 14 m water depth offshore the Tagliamento river delta, where the bottomset of the late Holocene clinoform is below seismic-reflection resolution. A $10-\mathrm{cm}$ thick mud section at the top of the core documents sediment deposition during the last $100 \mathrm{yr}$, based on ${ }^{210} \mathrm{~Pb}$ activity profile (Frignani et al., 2005). Interestingly, this mud section represents also the only late Holocene sediment above a depositional hiatus that corresponds to the downlap surface of the late Holocene clinoform (the mfs, white dashed line). Due to the limited water depth of the Tagliamento bottomset, sediment is swept by storm waves and its preservation potential is likely very low, with a residence time of sediment in the order of a century (limit of ${ }^{210} \mathrm{~Pb}$ activity measurements) rather than millennia. 
Figure 7. Indirect evidence of strong bottom currents in the bottomset of the central Adriatic clinoform. A) Bathymetry and B) backscatter data from a multibeam EM3000 survey around the Gargano Promontory. A) shows grey scale of shadow-relief and bathymetry in color, B) grey scale of shadow-relief and backscatter in color. Note an area of high backscatter (arrow) that could indicate an area swept by bottom currents. C) Map of superficial sediment around the Gargano promontory (from Sigl, 1973) showing that the coarser sediment has an elongated distribution around the promontory, possibly reflecting the action of currents. D) Slope gradient map north of the Gargano promontory highlighting West-East trend in an area characterised by seafloor mud reliefs (Trincardi et al., 2000); this trend is an indication of shore-parallel current.

Figure 8. Indirect evidence of strong bottom currents in the bottomset of the central Adriatic clinoform. A), B) Digital Terrain Models from EM3000 multibeam survey in a bottomset area affected by seafloor irregularities (mud reliefs; location on Fig. 1). C) Thickness map of the late Holocene clinoform above mfs. D) Seismic-reflection profile CSS51. Note in all the images the strongly asymmetric shape of each seafloor bump with preferential sediment accumulation on the updrift side (NW). The origin of the mud reliefs is possibly related to fluid flow escape and sediment deformation (see Trincardi et al., 2000; Correggiari et al., 2001; Cattaneo et al., 2004b).

Figure 9. Scheme of the distribution of "Concentration" and "Activity" versus distance offshore (modified from McCave, 1972, his Fig. 94, p. 235), showing the dynamics of advective transport of a "mud stream" on a continental shelf with four possible cases where "Activity" represents "a notational parameter combining wave and tidal effects". The scheme was modified by adding the observations of Ogston et al. (in press) that here are reported in brakets (muddy coast, clinoform, mid-shelf mud deposit). It is here highlighted a possible "downcurrent evolution" of shelf mud deposits similar to the case of the Adriatic (from north to south) for cases A to $\mathrm{C}$.

Figure 10. A) Qualitative sketch of an advection-dominated mud clinoform on the shelf, summarising a situation like that of the Ganges-Brahmaputra (Michels et al., 1998; see Fig. 4). B) A similar cartoon adapted to the case of the Adriatic, where the presence of a coastal outbulges causes an increase in bottom current energy and a consequent limitation of the 
offshore extent of the bottomset. C, D) Sections CC' and DD' (located in skeme B) cross the muddy clinoform in distinct water depth ranges, and the limiting factor controlling clinoform growth are different: C) a shallow-water clinoform such as the Tagliamento or Po prodeltas has a bottomset with sediment accumulation limited by wave action; D) the Gargano clinoform appears limited by waves at the topset, and bottom currents at the bottomset. 


\begin{tabular}{|l|l|l|l|l|l|}
\hline Core name & latN & lonE & $\begin{array}{l}\text { water } \\
\text { depth }\end{array}$ & $\begin{array}{l}\text { core } \\
\text { length }\end{array}$ & reference \\
\hline VE04-19 & 45.610088 & 13.111040 & 12.9 & 3.13 & This paper \\
VE04-21 & 45.616898 & 13.105548 & 9.9 & 3.08 & This paper \\
GRA87-599 & 45.6100 & 13.1333 & 14 & 0.25 & Frignani et al., 2005 \\
AN97-2 & 43.877344 & 13.336458 & 39.3 & 5.63 & Correggiari et al., 2005a \\
AN97-15 & 43.754547 & 13.641969 & 55.1 & 4.26 & Correggiari et al., 2001 \\
CSS00-5 & 42.488057 & 14.468737 & 81.96 & 6.92 & Trincardi et al., 2000 \\
PAL94-9 & 42.584908 & 14.493184 & 104.4 & 6.78 & Trincardi et al., 1996 \\
PAL94-8 & 42.666429 & 14.618446 & 149.5 & 5.04 & Trincardi et al., 1996 \\
AMC99-1 & 42.863283 & 14.761483 & 259.95 & 9.04 & This paper \\
RF93-30 & 42.066883 & 15.6676 & 77.3 & 6.27 & Oldfield et al., 2003 \\
\hline
\end{tabular}

Table 1. Location of the sediment cores presented in this paper and reference to papers containing informations on them. 


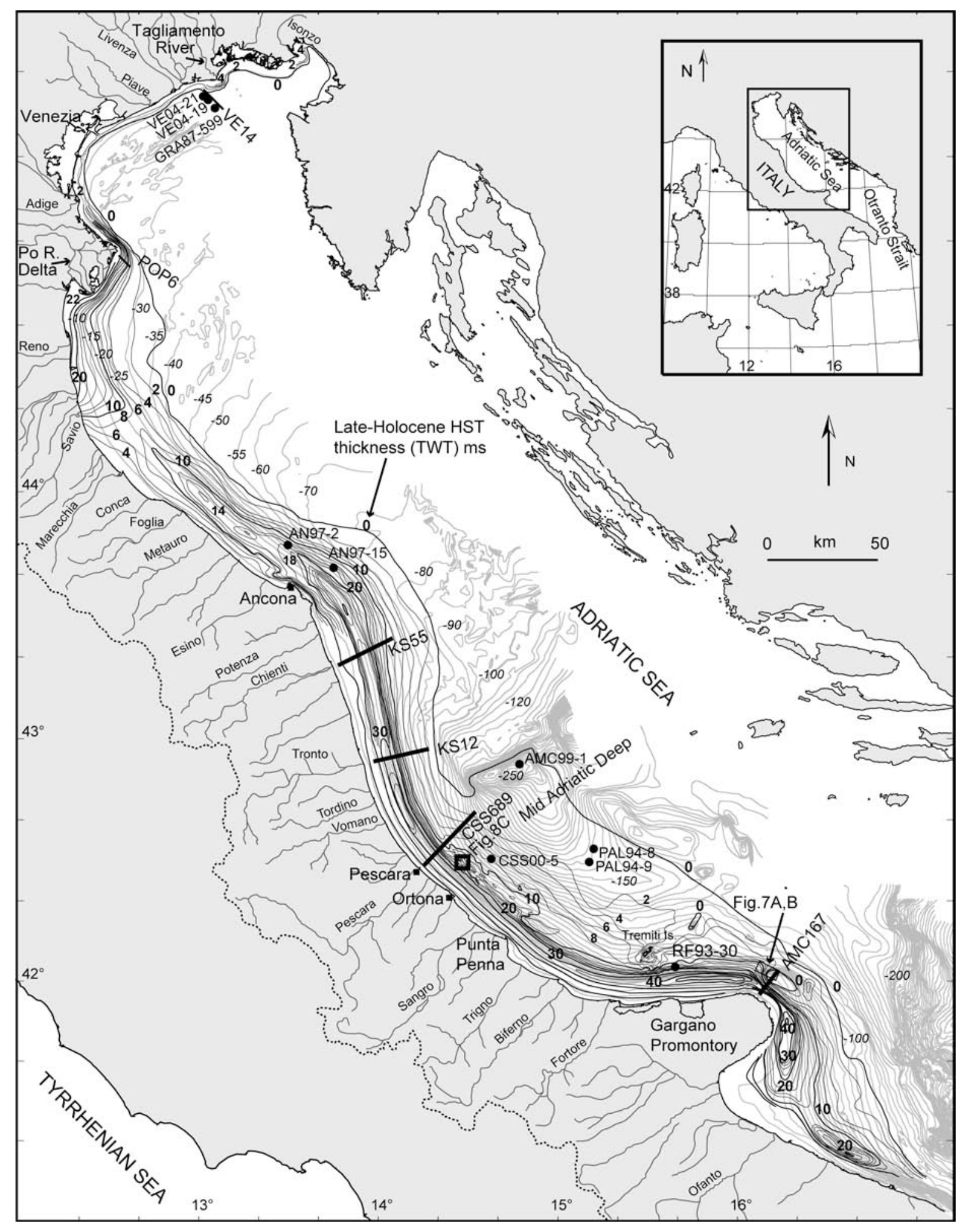

Figure 1 

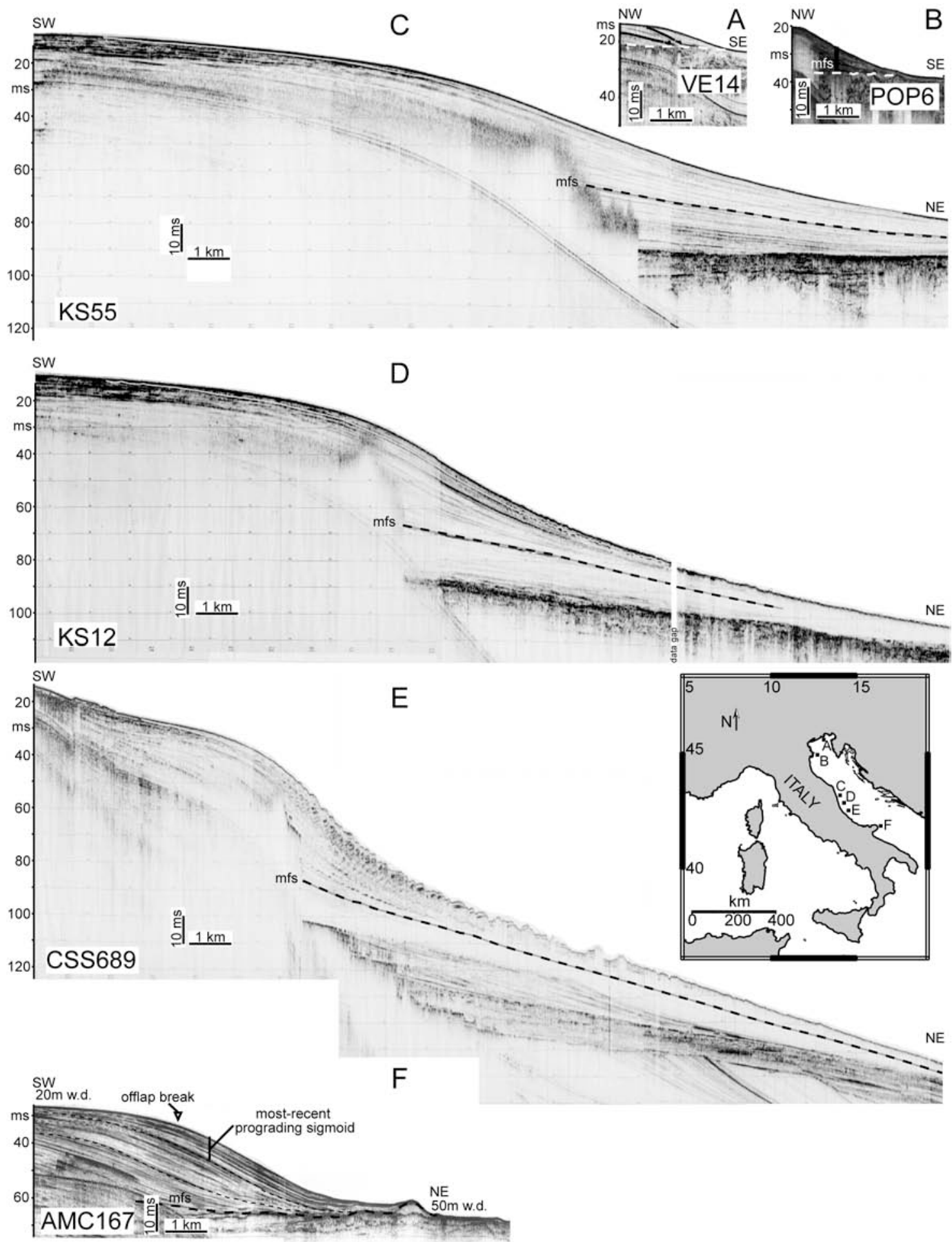

Figure 2 


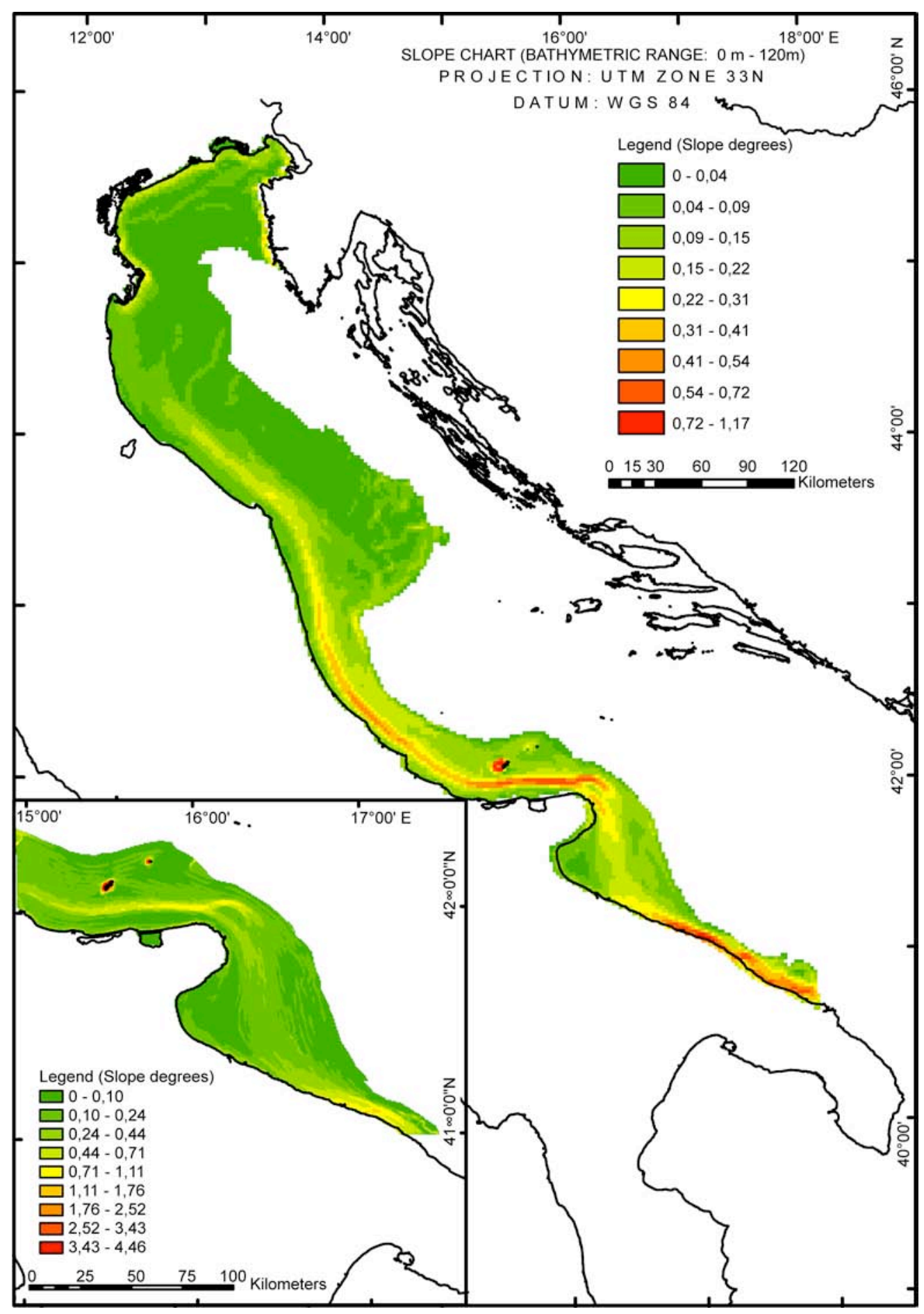

Figure 3 

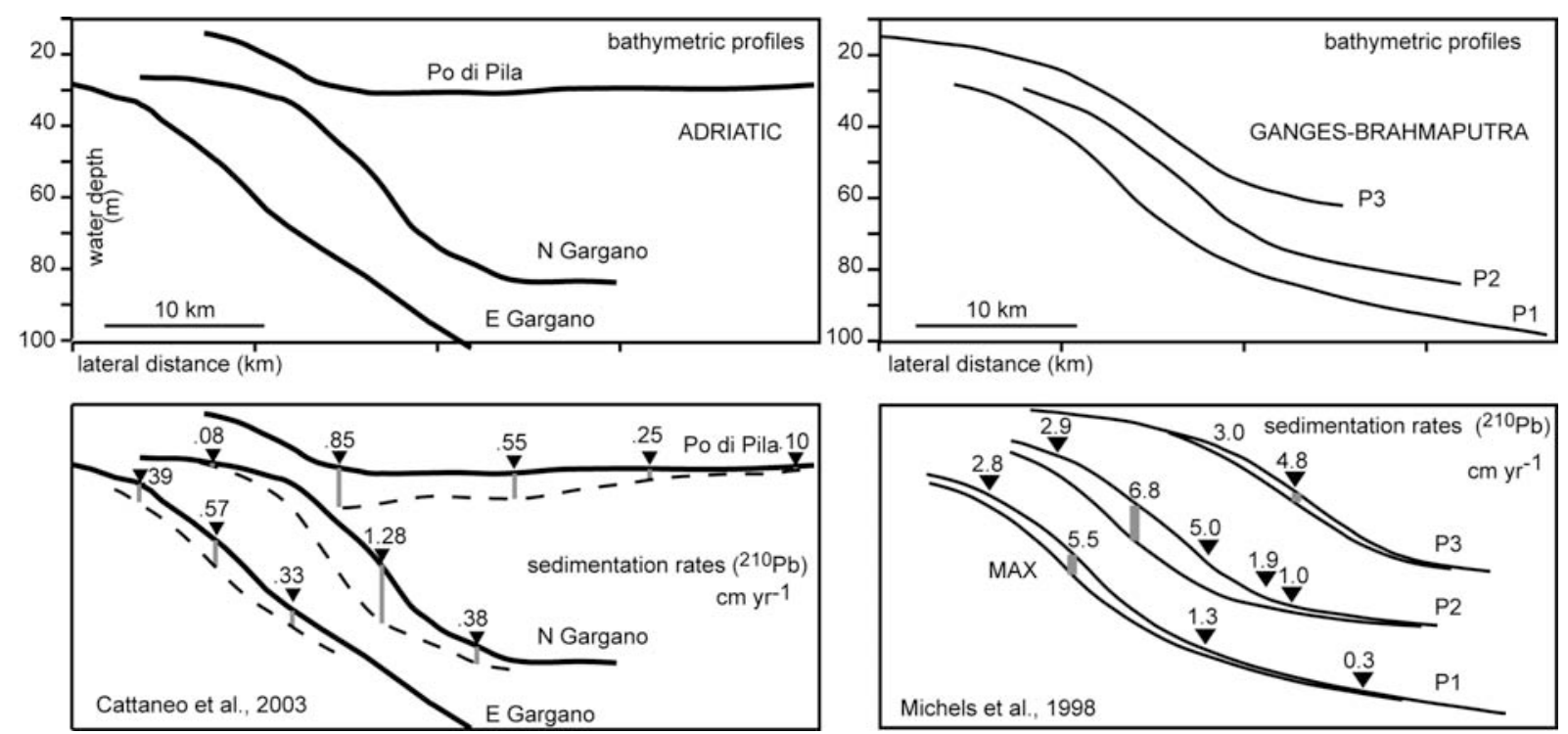

Figure 4 


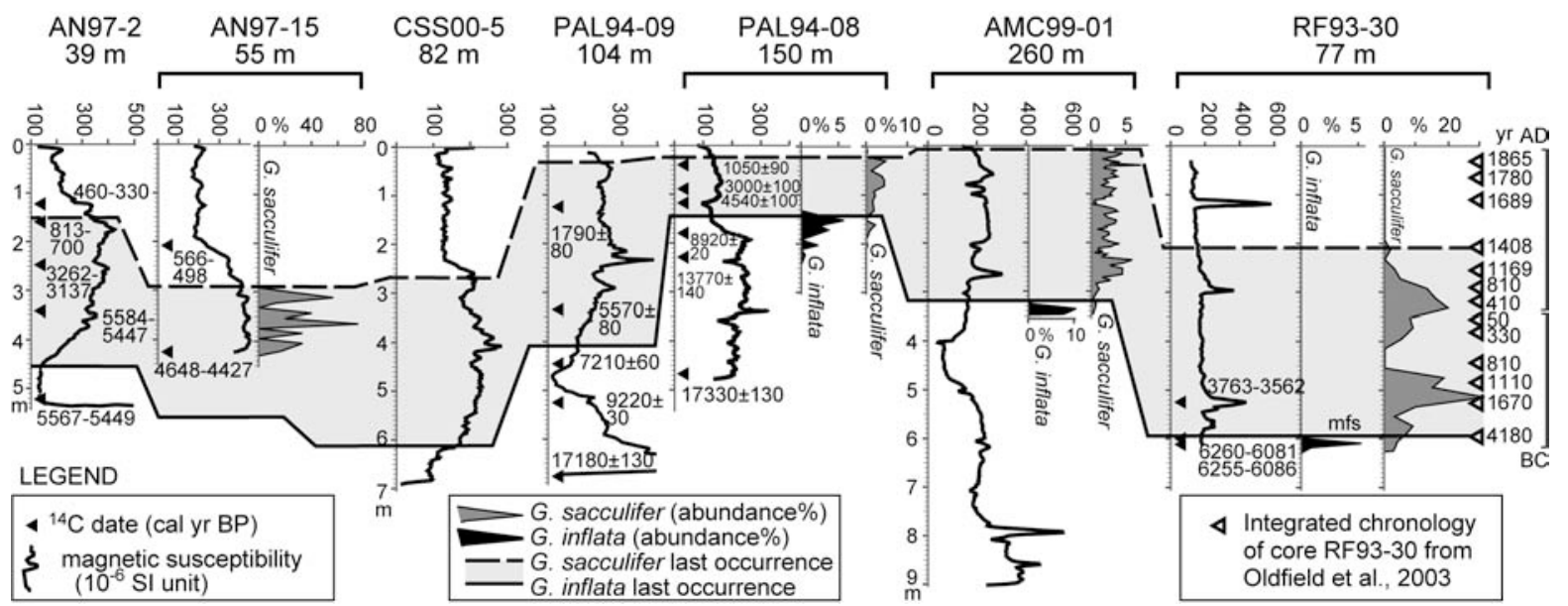

Figure 5 

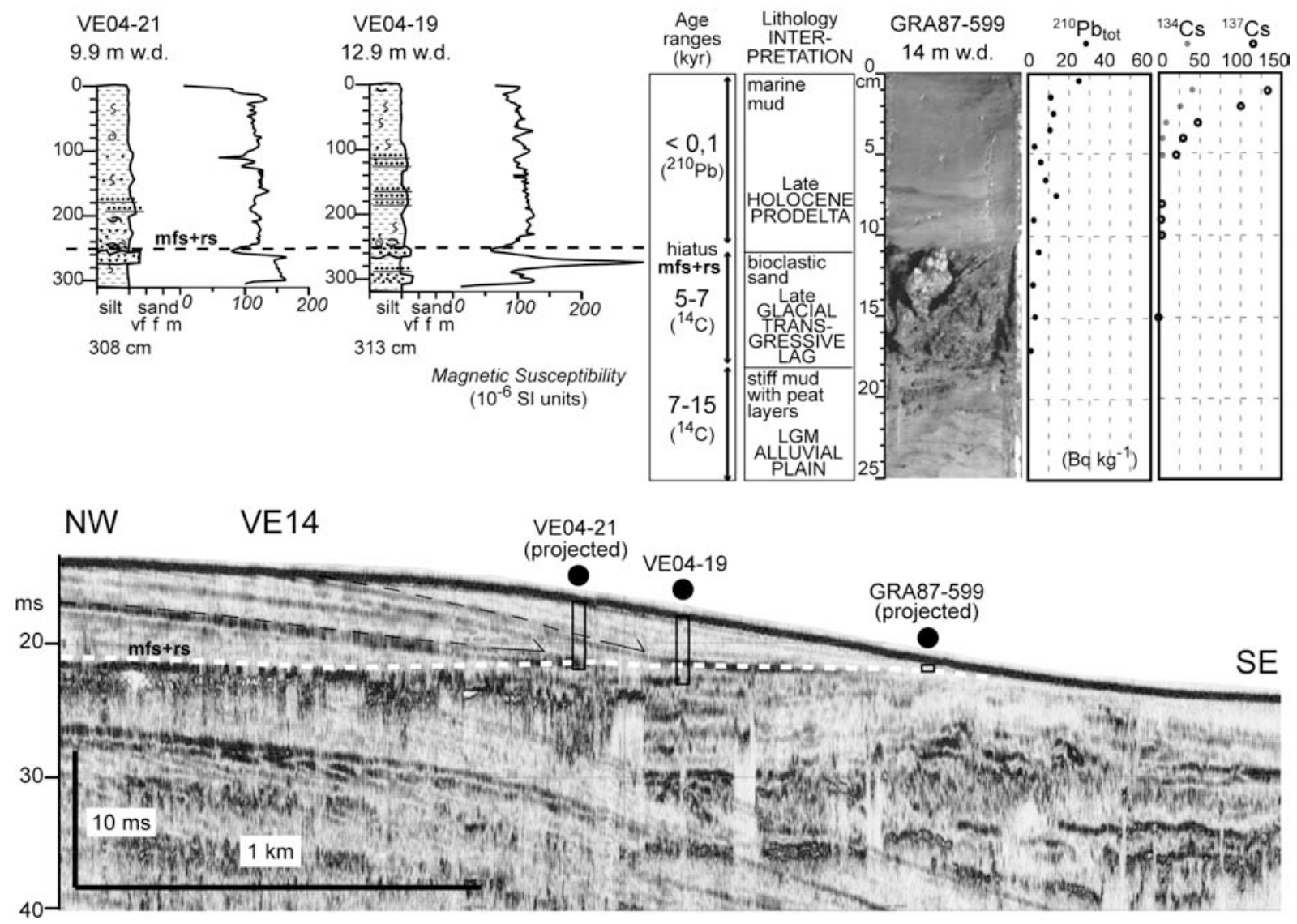

Figure 6 

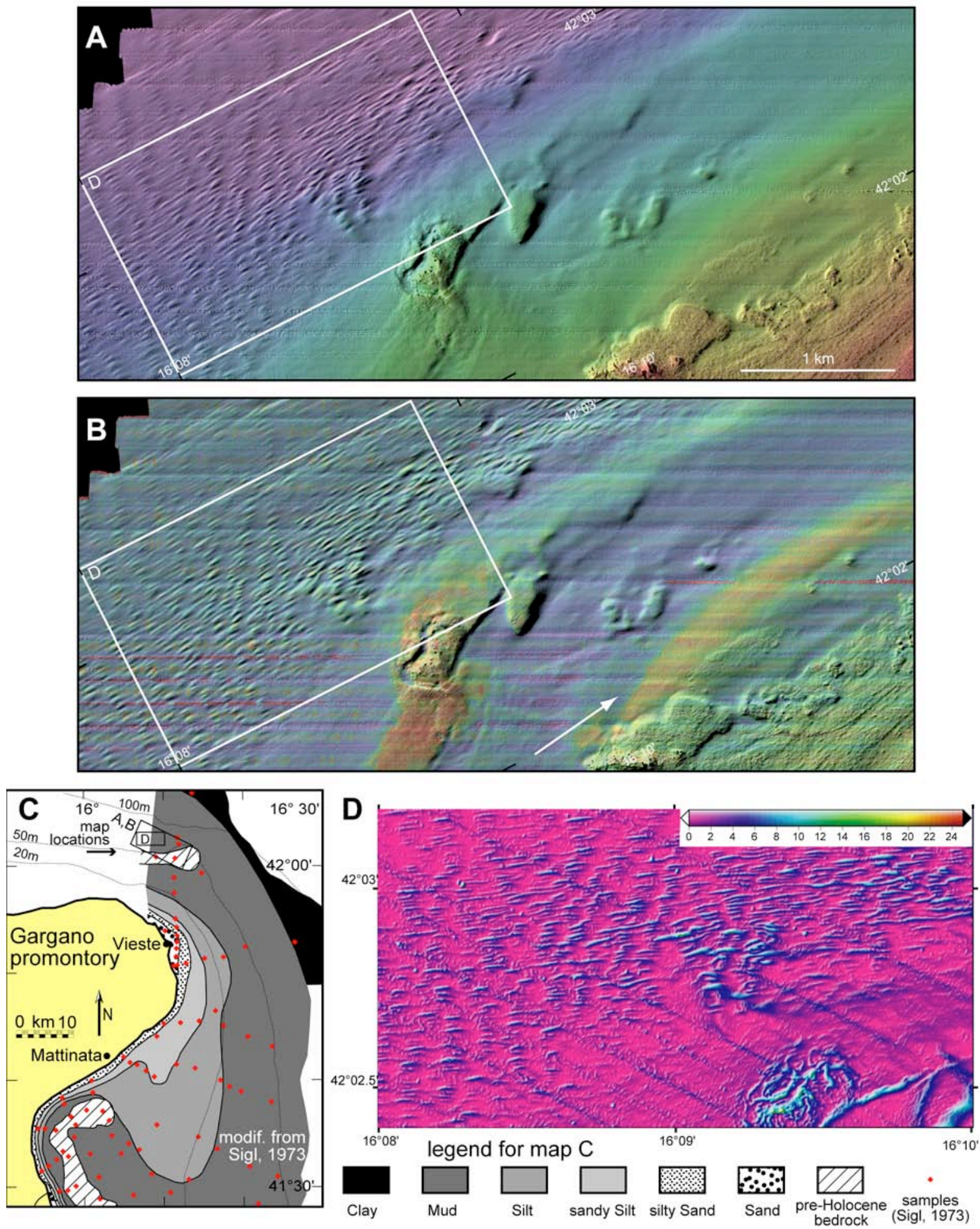

Figure 7 


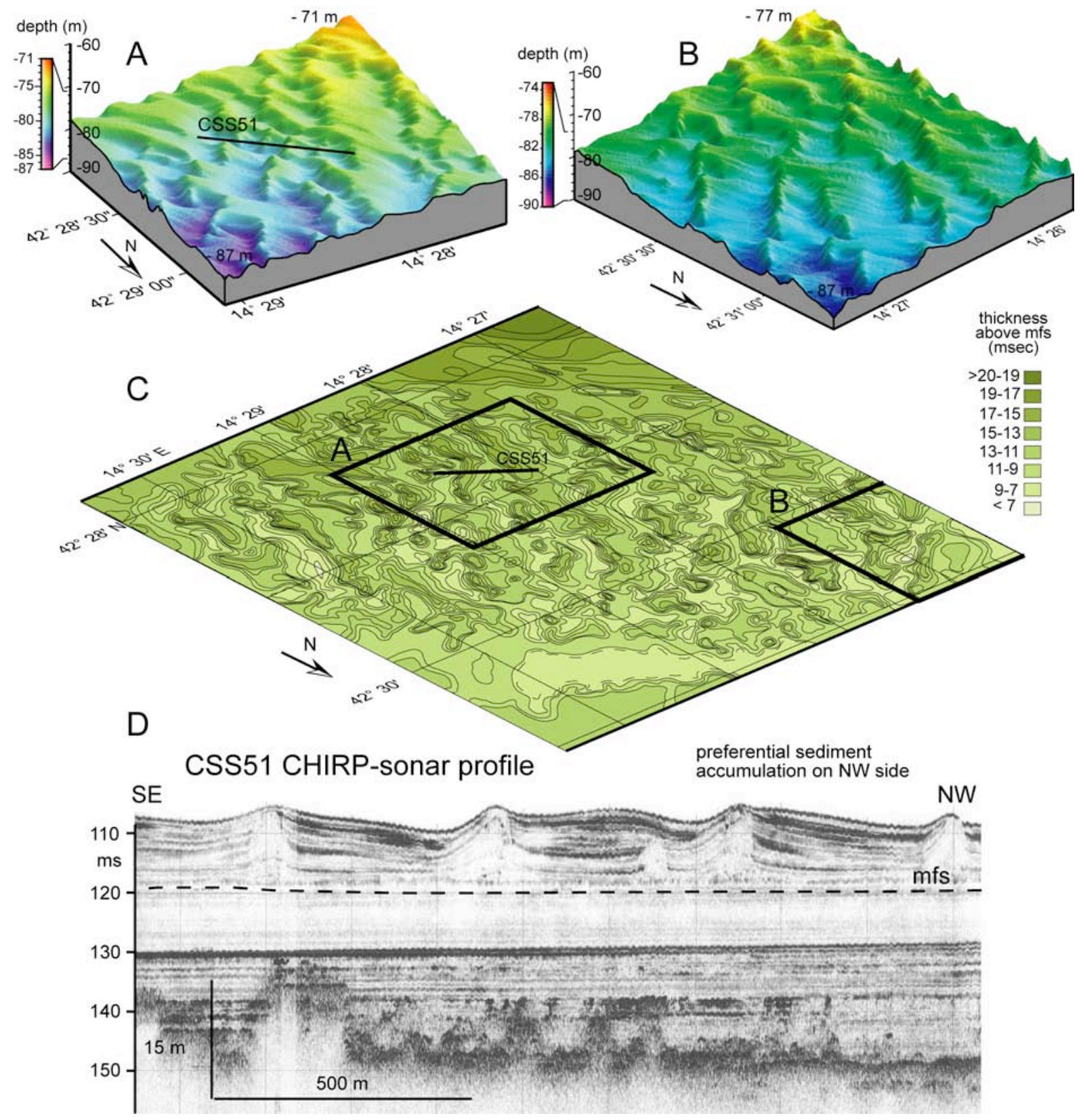

Figure 8 


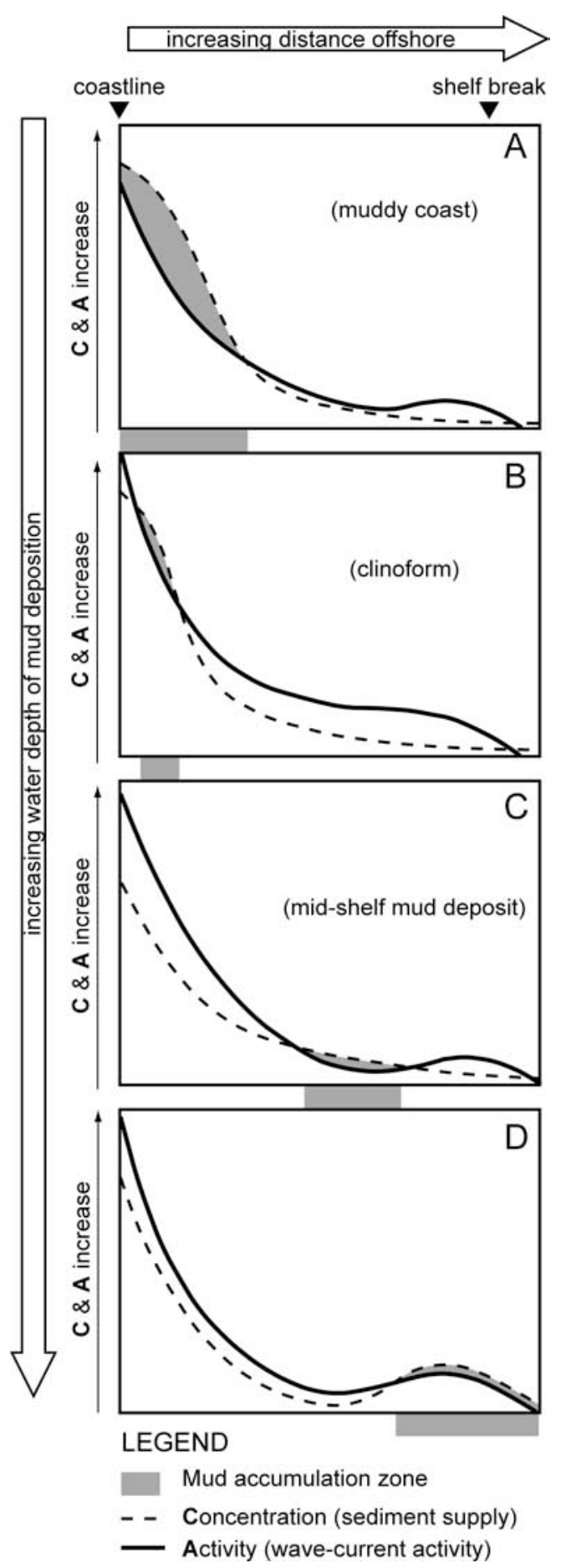

Figure 9 


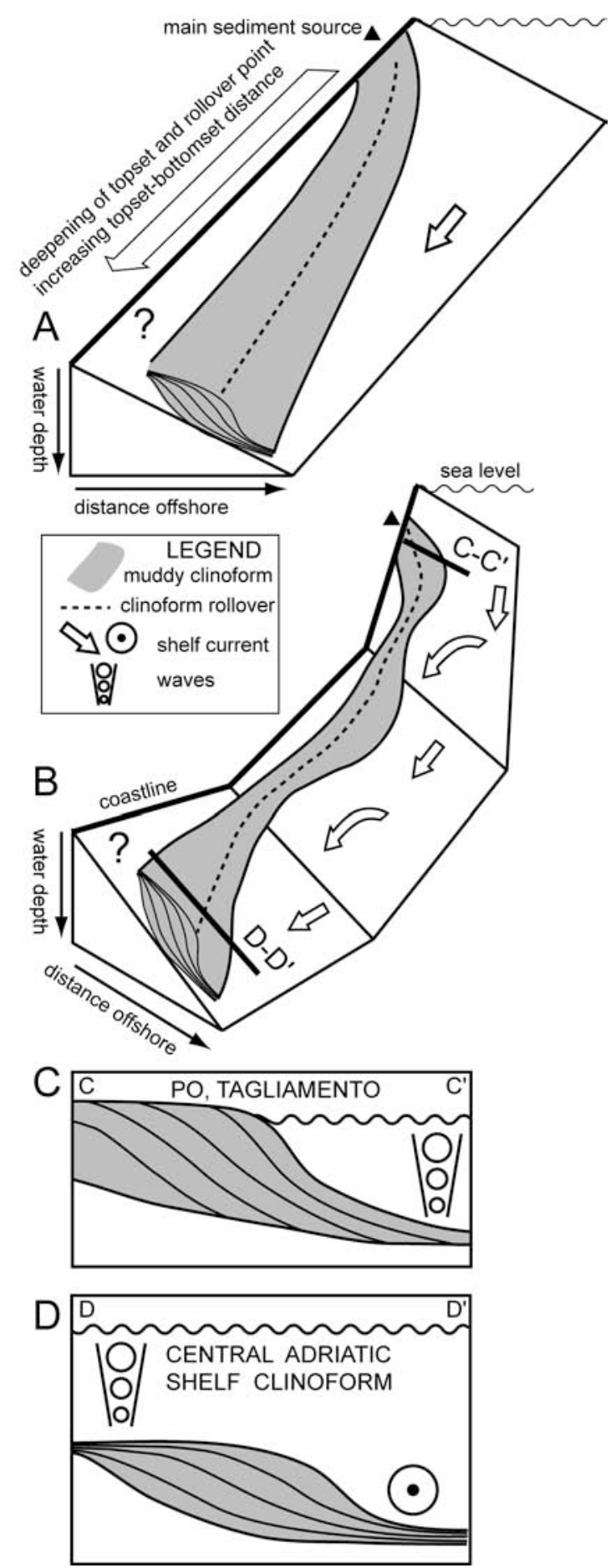

Figure 10 